\title{
Gesäuse - An Alpine National Park of endemic species and biodiversity research
}

\author{
Christian Komposch \& Daniel Kreiner
}

Keywords: endemism, biodiversity, research, faunistic, floristic, experts, glaciation, nature conservation, Eastern Alps

\section{Abstract}

This paper deals with species whose ranges lie entirely (endemics) or predominantly (subendemics) within the political borders of Austria or the geographical borders of the Alps. The current overview of endemic and subendemic species of the Gesäuse National Park shows 195 animal and 30 plant species. This protected area is a hotspot of endemisms in the Eastern Alps and has exceptional biodiversity. The National Park is also a centre of endemism research, although the grave lack of experts and financing are serious limitations on the research.
Profile

Protected area

Gesäuse National Park

Mountain range

Alps, Austria

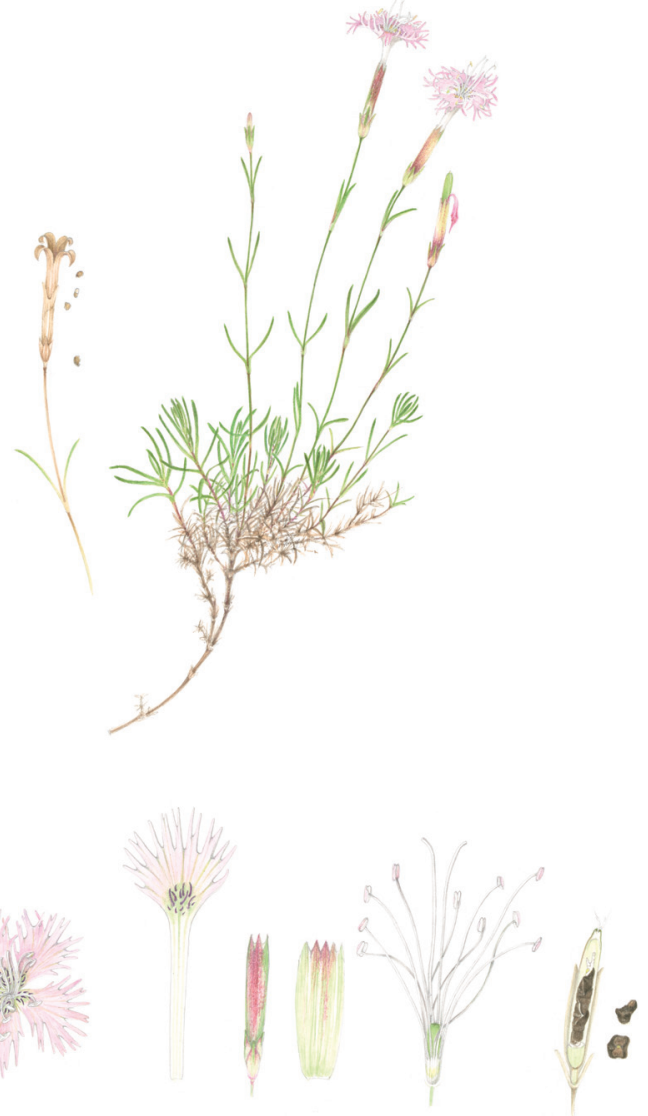

Figure 1 - Dianthus plumarius ssp. blandus is a regional endemic plant with major populations in the Gesäuse NP. Illustration by Margareta Pertl. (C) Nationalpark. Gesäuse GmbH

\section{Introduction}

"Endemic species are the most interesting topic of faunistics and biogeography, a national contribution to global biodiversity and the biological treasure of any country." Komposch (2010, p. 21)

The Gesäuse National Park (NP) is Austria's youngest National Park. It was founded in 2002 and accredited by the IUCN in 2003 . The protected area is thus only a few years older than the Journal on Pro- tected Mountain Areas Research and Management called eco.mont. Since the beginning, the Gesäuse NP has devoted itself to biodiversity research, and since 2010 it has published results from the fields of conservation management and science in eco.mont on a regular basis. A case in point about the rugged wilderness of the Gesäuse NP was published in 2010 and shows the holistic approach of the NP administration, which includes nature conservation measures and renaturation projects, environmental education and visitor management, as well as research concerning biodiversity at all levels (Sterl \& Kreiner 2010). In 2016, there followed an analysis of 10 years of research in the Gesäuse NP (Maringer \& Kreiner 2016). In 2009, the importance of the NP as a hotspot of endemic species in Austria had already been highlighted (Rabitsch \& Essl 2009). In the following issue of eco.mont (Komposch 2010), this central role was shown again in the case of harvestmen and spiders in the Northern Limestone Alps, especially in the Gesäuse NP.

After intensified research during the last three years, more accurate numbers with regard to endemic plant and animal species in the Gesäuse can now be presented.

\section{The endemic fauna and flora of the Gesäuse NP}

Endemic species are the single most important feature of the Gesäuse NP (Komposch \& Paill 2012). The most iconic of the region's endemic plants is the Pretty Feathered Pink (Dianthus plumarius ssp. blandus, Figure 1); its known occurrence lies within a corridor of about $80 \mathrm{~km}$ by $30 \mathrm{~km}$ in the Northern Limestone Alps. The largest and most important populations are situated within the Gesäuse NP (Köppl \& Oberklammer 2018). It is one of 23 endemic and subendemic plant species in the Northern Limestone Alps. In total, 30 plant species occur in the Gesäuse NP which are endemic to Austria (Rabitsch \& Essl 2009).

The fauna, too, of the Gesäuse is rich in endemic species. The current number of recorded endemic 


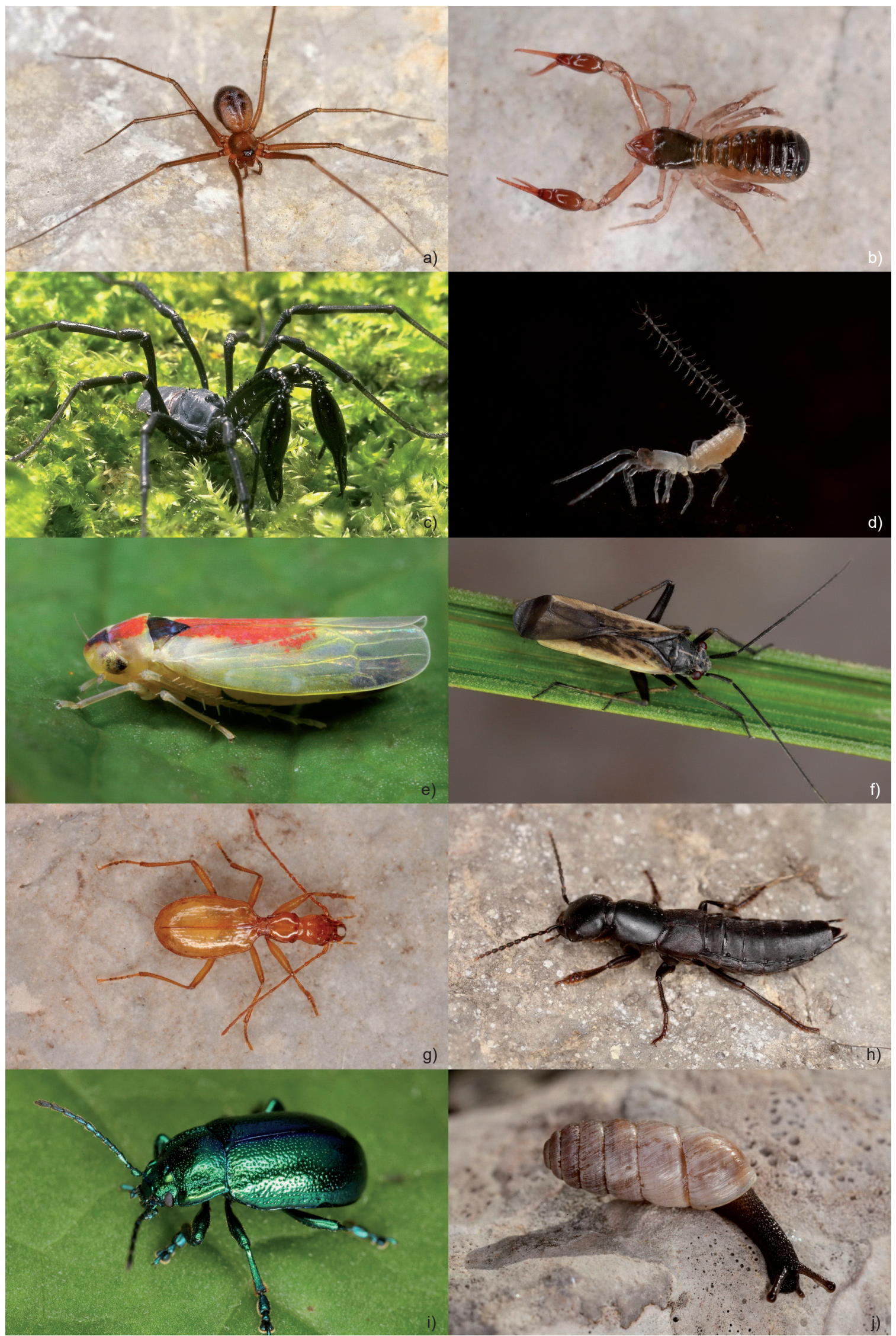

Figure 2 - Zoological endemics occurring in the Gesäuse National Park: $a$ : Troglohyphantes subalpinus (Araneae), b: Chthonius sp. (Pseudoscorpiones), c: Ischyropsalis kollari (Opiliones), d: Eukoenenia sp. (Palpigradi), e: Zygina hypermaculata (Auchenorrbyncha), f: Dimorphocoris schmidti (Heteroptera), g: Arctaphaenops angulipennis styriacus (Carabidae, Coleoptera), h: Ocypus brevipennis (Staphylinidae, Col.), $i$ : Oreina elongata styriaca (Chrysomelidae, Col.), $j$ : Cylindrus obtusus (Gastropoda). (C) Ch. Komposch, ÖKOTEAM \& G. Kun₹. 


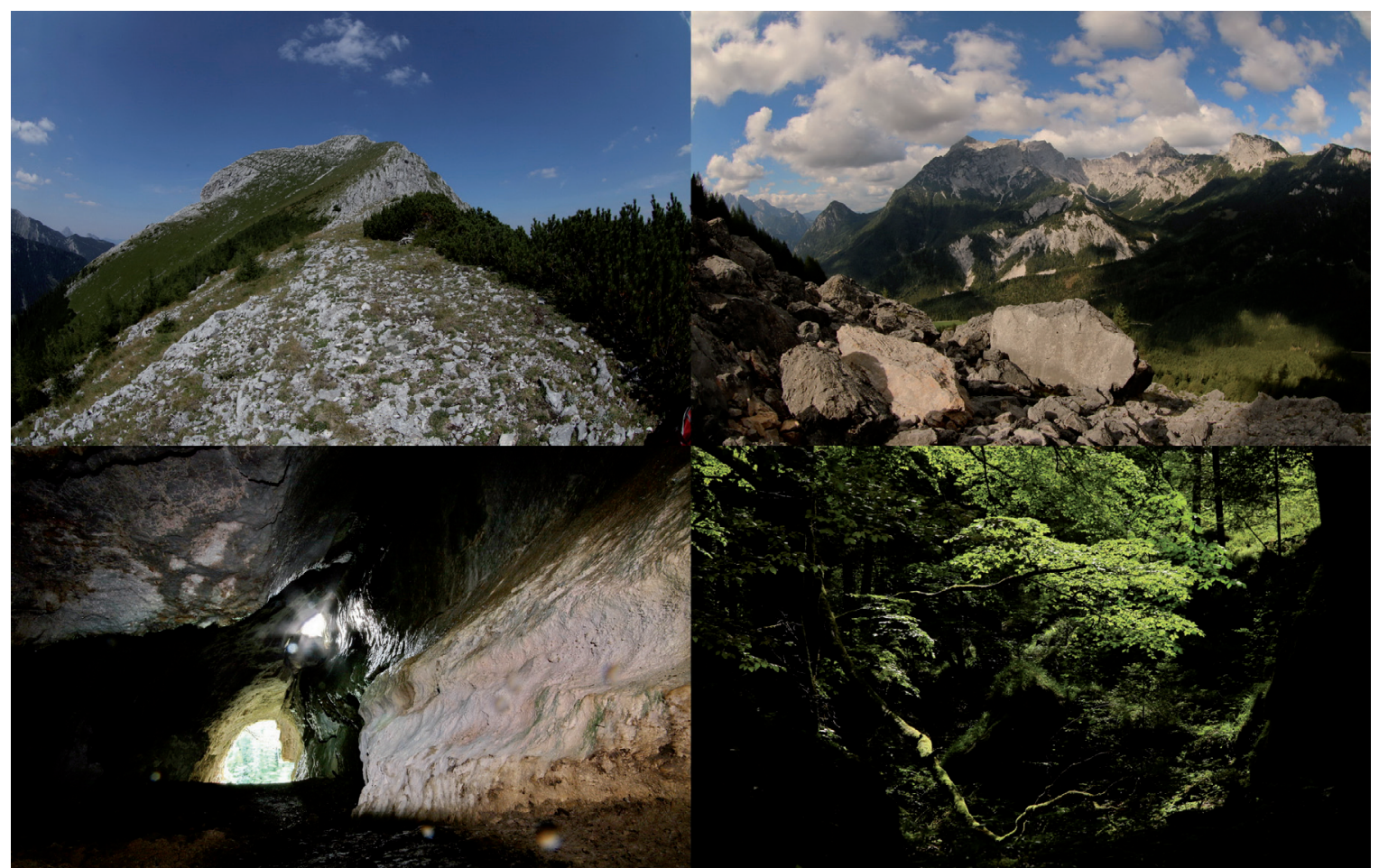

Figure 3 - Important habitat types for endemic animal species: alpine habitats (Unterlugauer), rocks and screes (Gstatterstein), caves (Steinkarböhle), natural forests (Hartelsgraben). (C) Ch. Komposch, ÖKOTEAM

species is 195 , plus an additional 14 pseudo-endemics. This remarkably high number of 209 endemics is composed of 190 terrestrial invertebrates: Coleoptera (70 spp.: Carabidae (31), Curculionidae, Chrysomelidae, etc. (24), Staphylinoidea (15)), Gastropoda (33), Araneae (22), Lepidoptera (13), Opiliones (11), Auchenorrhyncha (10), Diplopoda (9), Heteroptera (6), Collembola (4), Isopoda (3), Oribatida (3), Pseudoscorpiones (2), Archaeognatha (2), Palpigradi (1) and Diplura (1) (Figure 2). Just 5 aquatic species can be called endemics: Trichoptera (3 spp.), Plecoptera (1), and Diptera: Limoniidae (1). The 14 pseudo-endemics belong to the taxon Rotifera.

These numbers differ from those given in earlier publications. The reasons for this are: (i) a broader definition of the term endemism concerning the fauna, which is necessary for conservation issues and the effective protection of the species (see Komposch 2018); (ii) the increase in both taxonomic knowledge and knowledge about the distribution of species; (iii) an updated record of species in the Gesäuse thanks to a deeper analysis of the literature and ongoing faunistic investigations. Further research activities and the consistent application of the broader definition of endemism for all taxa will lead to a greater number of endemics in the Gesäuse NP. Estimates anticipate a total number of 250 endemic animal species in the Gesäuse. The most promising habitat types are rocks, tali, caves, canyons, natural forests, alpine meadows and screes (Figure 3).

\section{Biodiversity research and the lack of resources}

There is a long and unique tradition, dating back to the beginning of the $20^{\text {th }}$ century, of investigating the phenomenon of endemism in the Alps. Intensive research efforts have been made by a long line of Austrian biologists, among them Rudolf Heberdey, Karl Holdhaus, Herbert Franz, Heinz Janetschek, Konrad Thaler and Peter Schönswetter, and by the Germans Gustaf De Lattin and Hermann Merxmüller. The main reasons for the recent appearance of fauna and the existence of species distributed in limited areas in the Alps are: (i) the large-scale extinction of fauna of the Eastern Alps during the last ice age; (ii) the evasion of the native species of the Alps from glaciation towards southern refugia, triggering evolutionary processes, and post-glacial re-immigration; (iii) the survival of certain species in so-called massifs de refuge unglaciated massifs at the periphery of the ice shields, in caves and on inner Alpine nunataks (Holdhaus 1954; De Lattin 1967; Janetschek 1956; Holderegger $\&$ Thiel-Egenter 2009). The diversity of endemic and subendemic spiders and harvestmen shows a SouthNorth and an East-West gradient, due to the specific patterns of glaciation in the region, and their survival and re-wandering processes (Rückwanderer auf kurze und weite Distan₹, sensu Holdhaus) in the Eastern Alps (see Muster 2001).

The Gesäuse can be regarded as having been well investigated historically from an arachnological and entomological point of view, thanks to the important 


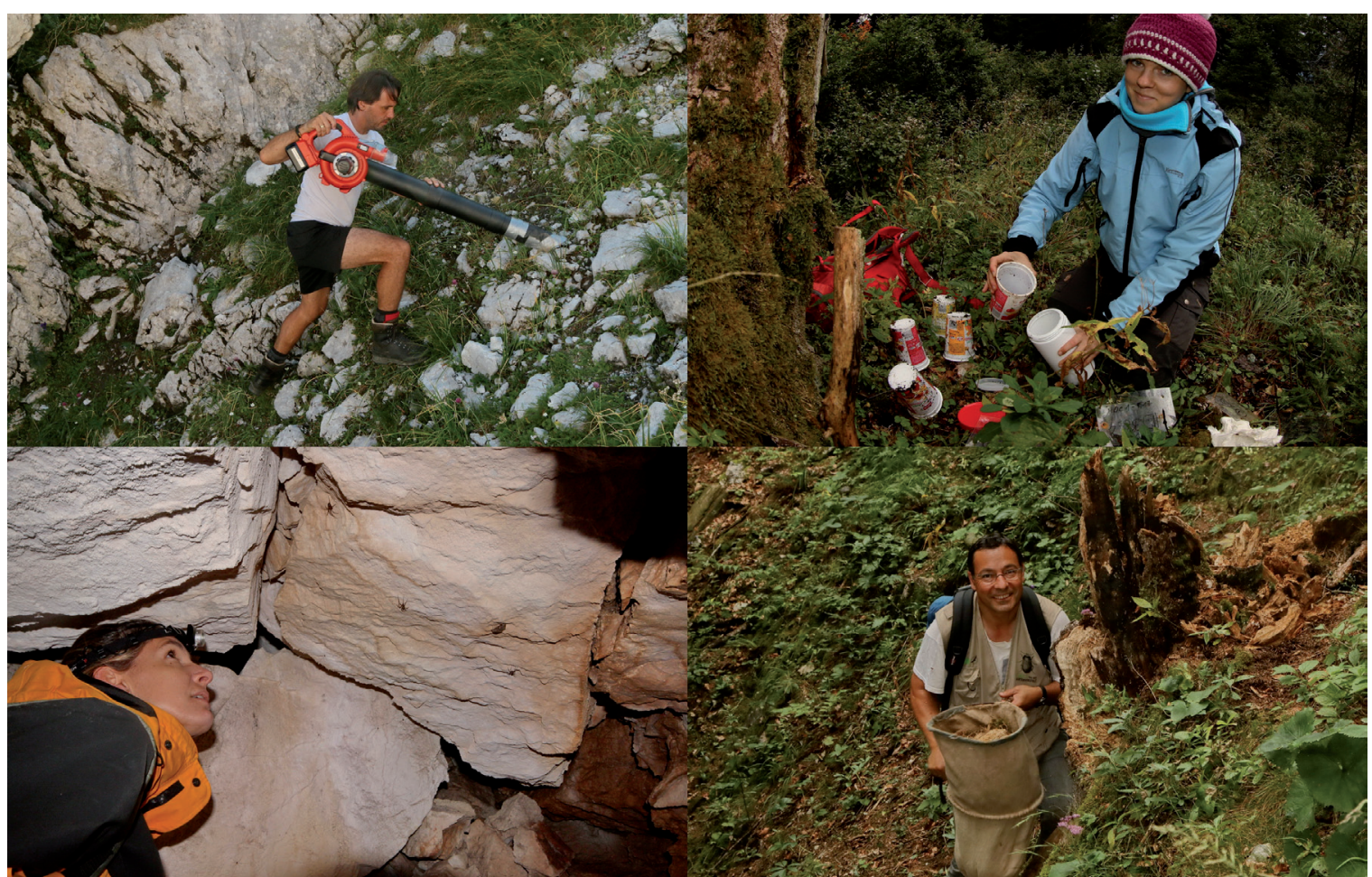

Figure 4 - Faunistic field work in the Gesäuse NP: suction sampler, pitfall traps, hand collecting, soil-sifter. (C) Ch. Komposch, ÖKOTEAM

zoologist Herbert Franz, who paid special faunistic interest to his Gesäuse Mountains around Admont from 1939 to 1951. Afterwards, faunistic research fell into a deep sleep until the NP was established in 2002. Nowadays, the situation for faunistic and taxonomic research is limited. Despite plenty of enthusiasm on the part of the few available field-experienced biologists, there is a dramatic lack of experts, funding, and interest and prioritization on the part of universities and conservation departments.

The Gesäuse NP is the only protected area in Austria focusing on establishing a complete inventory of endemic species within its borders. The difficulties besides the taxonomic ones and financial constraints - start in building a team of experts. For several taxa, there are no longer any specialists in Austria, and the few Central European taxonomists are in many cases totally overloaded with work and requests. This situation can be demonstrated by giving a few examples from our present endemism project:

- Palpigradi: there is just one person, Erhard Christian, dealing with this arachnid group worldwide.

Pseudoscorpiones: only a few experts are available in Europe; the Gesäuse has been investigated by the German arachnologist Christoph Muster.

Diplura: the samples collected have been examined and identified by the Spanish specialist Alberto Sendra, who works at the University of Alcalá Henares. Collembola: although springtails are a ubiquitous group, so far no expert with spare working capacity has been found to deal with the extensive samples from the NP.
- Lumbricidae: despite the immense pedobiological importance of this taxon, already emphasized by Charles Darwin in 1881, no zoologist in Austria has the in-depth knowledge to identify earthworms at species level.

Considering the importance of biodiversity research and taxonomy, it could be expected that there are plenty of biologists. But the opposite is true: at Austrian universities, knowledge of species is not valued and is consequently disappearing more and more. Klausnitzer (2007) even states that for students and young scientists it is almost harmful to deal with faunistics and taxonomy. A university career based on these branches of science is almost impossible, as taxonomy is being replaced by genetics. Most of the highimpact journals (e.g. Systematic Biology, Molecular Ecology) even refuse manuscripts with taxonomic descriptions of new species, let alone those presenting faunistic data. In 1988 , less than $1 \%$ of known species were the subject of scientific research - and the situation has become worse (Kropf 1996). Last but not least, in recent decades most federal conservation departments and NPs have been focusing on fulfilling Natura 2000 targets, with less time and more limited finances to deal with endemics and their need for protection.

\section{Future research}

So far in the Gesäuse NP, taxa have been investigated within the following 14 zoological groups: Arachnida: Araneae, Opiliones, Palpigradi, Pseudoscorpiones; Insecta: Auchenorrhyncha, Coleoptera (Carabidae, 
Staphylinoidea, Curculionidae, Chrysomelidae, etc.), Diplura, Heteroptera, Lepidoptera, Plecoptera, Trichoptera; Mollusca: Gastropoda (Figure 4). Further faunistic and taxonomic research on endemic taxa is planned. The aim of this ambitious project is to develop a complete catalogue of endemic plants and animals in the Gesäuse NP by 2025 .

\section{Acknowledgements}

We are grateful to Herbert Wölger for supporting biodiversity research, to Heri Wagner and Michaela Sterl for useful comments, and to Valerie Braun for taking care of this valuable scientific journal. Thanks go to our experts from the endemic project, Sandra Aurenhammer, Erhard Christian, Gregor Degasperi, Thomas Dejaco, Thomas Frieß, Erwin Holzer, Werner E. Holzinger, Christoph Muster, Wolfgang Paill, Manfred Schneider, Alberto Sendra and Johannes Volkmer. The work presented here was carried out within the framework of the Austrian programme for rural development LE 2014-2020; project Schutrgutinventar-ANr.: 761A/2015/35).

\section{References}

Franz, H. 1954. Die Nordostalpen im Spiegel ibrer Landtierwelt. Eine Gebietsmonographie. [In German]

Holderegger, R. \& C. Thiel-Egenter 2009. A discussion of different types of glacial refugia used in mountain biogeography and phylogeography. Journal of Biogeography 36: 476-480.

De Lattin, G. 1967. Grundriß der Zoogeographie. Stuttgart. [In German]

Klausnitzer, B. 2007. Faunistik als Zukunftswissenschaft. Entomologische Zeitschrift 117: 3-6. [In German]

Holdhaus, K. 1954. Die Spuren der Eiszeit in der Tierwelt Europas. Abhandlungen der zoologisch-botanischen Gesellschaft in Wien 18: 1-493, Taf. 1-52. [In German]

Janetschek, H. 1956. Das Problem der inneralpinen Eiszeitüberdauerung durch Tiere (Ein Beitrag zur Geschichte der Nivalfauna). Österreichische Zoologische Zeitschrift 6: 421-506. [In German]

Komposch, Ch. 2010. Alpine treasures - Austrian endemic arachnids in Gesäuse National Park. eco.mont - Journal on Protected Mountain Areas Research and Management 2(2): 21-28.

Komposch, Ch. 2018. A new classification of endemic species of Austria for nature conservation issues. In: Bauch, K. (ed.): $6^{\text {th }}$ Symposium for Research in Protected Areas, 2-3 November 2017, Salzburg, Austria, Conference Volume.

Komposch, Ch. \& W. Paill 2012. Endemiten im Nationalpark Gesäuse - alpine Schätze der Tierwelt Ös- terreichs. In: Kreiner, D. \& A. Maringer (eds.), Erste Dekade - Forschung im Nationalpark Gesäuse. Schriften des Nationalparks Gesäuse 9: 62-69. [In German]

Kropf, Ch. 1996. Biosystematische Forschung am Museum - eine Standortbestimmung. Jabrbuch des Naturbistorischen Museums Bern 12: 137-159. [In German]

Köppl W. \& I. Oberklammer 2018. Dianthus plumarius subsp. blandus - Distribution and Habitat Features. In: Bauch, K. (ed.): $6^{\text {th }}$ Symposium for Research in Protected Areas, 2-3 November 2017, Salzburg, Austria, Conference Volume.

Maringer, A. \& D. Kreiner 2016. 10 Years of research in Gesäuse National Park: An overview of the research publications of the young protected area. eco. mont - Journal on Protected Mountain Areas Research and Management 8(2): 62-67.

Muster, C. 2001. Biogeographie von Spinnentieren der mittleren Nordalpen (Arachnida: Araneae, Opiliones, Pseudoscorpiones). Verhandlungen des Naturwissenschaftlichen Vereins in Hamburg 39: 5-196. [In German]

Rabitsch, W. \& F. Essl (eds.) 2009. Endemiten - Kostbarkeiten in Österreichs Pflanzen- und Tierwelt. Klagenfurt \& Wien.

Sterl, P. \& D. Kreiner 2010. A Case in Point. Gesäuse National Park - a rugged wilderness. eco.mont - Journal on Protected Mountain Areas Research and Management 2(1): 39-48.

\section{Authors}

\section{Christian Komposch}

is a zoologist and a director of the company ÖKOTEAM. He is a private researcher and a lecturer at the University of Graz and the FH in Klagenfurt. His main fields of research include arachnid taxonomy and ecology, endemism, alien species, red lists, and nature conservation evaluations. He has carried out faunistic research in the Gesäuse since 1992. Ökoteam - Institute for Animal Ecology and Landscape Planning, Bergmanngasse 22, 8010 Graz, Austria. www. oekoteam.at.E-mail: c.komposch@oekoteam.at

\section{Daniel Kreiner}

is a botanist and the head of the department for nature conservation and research in Gesäuse National Park. His main fields of research are habitat mapping and evaluation, biodiversity research, GIS mapping and modelling, land-use change, habitat dynamics (historical analyses, remote sensing) and nature conservation management. Nationalpark Gesäuse GmbH, Department for Nature Conservation \& Research, Weng 2, 8913 Admont. www.nationalpark.co.at. E-mail: daniel.kreiner@nationalpark.co.at

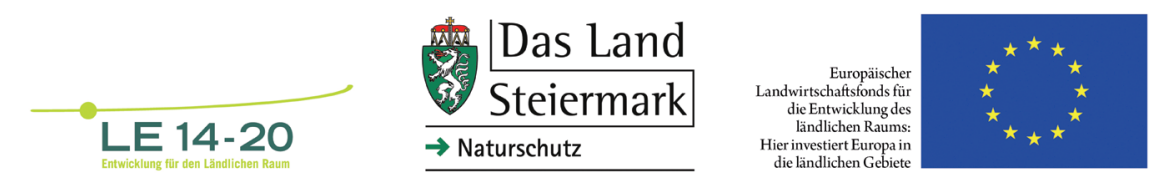

